\title{
GLOBAL COLLABORATIVE ADVANTAGE Efforts Toward Decolonization of Business Ethics and Management Scholarship
}

\author{
RUBINÁ MAHSUD (corresponding author) \\ Albers School of Business and Economics \\ Seattle University, Seattle, WA, U.S.A. \\ mahsudru@seattleu.edu
}

JESSICA LUDESCHER IMANAKA

Albers School of Business and Economics

Seattle University, Seattle, WA, U.S.A.

imankaj@seattleu.edu

\begin{abstract}
The current trend of prescribing and enforcing ethical business constructs, models, and frameworks developed in and by the Global North has become a new form of paternalistic colonizing of the Global South. Such behavior dangerously mirrors historically oppressive movements through colonization and continues extractive and damaging practices. Indeed, the enforcement of Northern constructs, models, and frameworks facilitates the maintenance of an artificial global hierarchy which continues to harm the South to the North's benefit. They overlook and prohibit any possible inclusion of ethical and philosophical frameworks derived from the wisdoms and traditions of the South.

This article advances the goal of Global Collaborative Advantage or GCA, which utilizes a decolonizing perspective within the field of business ethics and strives for a stronger incorporation of diverse sources of wisdom from the Global South. GCA calls for a Southled thought and action process, bringing the world's wisdom traditions together while it de-centers Euro-originated perspectives and centers those from the South. It offers a model of relational exchange in markets for business organizations rather than the current transactional-exchange-focused system, and calls for a truth and reconciliation process, among other recommendations. This article thus makes the case for developing a model that draws from a variety of global perspectives on humanity, society, and economics to broaden the possibilities for ethical, meaningful, and generative exchange in global markets.
\end{abstract}




\section{KEYWORDS}

Global Collaborative Advantage; CSR; corporate citizenship; decolonization; Global North; Global South

Poverty, disease, inequitable resource distribution, environmental degradation, and other injustices are suffered mainly in the Global South, yet the ones who commonly develop and promulgate dominant solutions to these problems are scholars from the Global North/West, and they do so without adequate incorporation of wisdoms, philosophies, and worldviews from the Global South. In fact, the Global North's economic prosperity did not coincide accidentally with the disparity of the Global South but rather is due to it (Moyo, 2010). Indeed, the historically inequitable treatment of the Global South and its people continues to allow the Global North to maintain both its economic and political power across the world (Perkins, 2016).

This article thus proposes the development of a new paradigm for business which we call Global Collaborative Advantage (GCA). This concept aims to inspire connections with diverse perspectives from across the globe and strives not only to harvest the best of the world's wisdom traditions in addressing pressing justice and equality challenges on the world stage but also to enable businesses even more to serve humanity's needs in authentic ways. Emerging from while seeking to transcend existing business ethics and CSR-related frameworks, models, and constructs, GCA brings an important multiplicity mindset to bear on global problems. It invites its participants to appreciate other viewpoints and systems of values, habits, and customs while also turning the mirror on those of us located in the Global North/ West who, as ethicists and academics, need to recognize our cultural biases and locate ourselves in our particular cultural history. GCA thus aims to foster openmindedness that can lead to real, lasting, and systemic change in the world.

We make the case for developing a model that draws from a variety of global perspectives on humanity, society, and economics to broaden the possibilities for ethical, meaningful, and generative exchange in global markets. First, we provide a literature review and discussion that offers a rationale for creating such a model. We then develop our tenets of GCA, explore the global political-economic context in which business ethics and CSR frameworks emerge and operate, and argue for a 
decolonizing outlook on existing macro-level global structures in ways that directly translate into how we conceptualize business and its responsibilities. We then build a model for GCA that involves four stages:

1. the incorporation of multiple perspectives, primarily from the Global South, in scholarship and practice;

2. a truth and reconciliation process;

3. the constellation of global institutions; and

4. a research and teaching program for scholars and educators that offers deep and meaningful critiques while also cultivating workable solutions.

\section{LITERATURE REVIEW: COLONIZING PERSPECTIVES IN BUSINESS ETHICS AND MANAGEMENT}

Some progress has truly been made over the past three to four decades in terms of establishing justice and care for the global commons through frameworks and models such as the stakeholder firm (Freeman, 1994; Kochan \& Rubinstein, 2000), the triple bottom line (Elkington, 1994; Norman \& MacDonald, 2004; Hussain, Rigoni, \& Orij, 2018), corporate social responsibility (Arthaud-Day, 2005; McWilliams \& Siegel, 2001), corporate citizenship (Matten \& Crane, 2005; Scherer, Palazzo, \& Matten, 2014; Scherer \& Palazzo, 2008; Logsdon \& Wood, 2002; Pies, Hielscher, \& Beckmann, 2009), integrative social contracts theory (Donaldson \& Dunfee, 1994; Hsieh, 2015; Strudler, 2015), international business norms (Windsor, 2004; Michaelson, 2010), human rights (Wettstein, 2012), partnerships (Glasbergen, 2011; Lasker, Weiss, \& Miller, 2001), and sustainability, to name a few.

And yet, how meaningful and impactful all of these frameworks and models really are is questionable. Some researchers have suggested that they have reached their limits; others have disparaged them as being superficial ploys and advertising (Lyon et al., 2018). More to the point, however, such models and frameworks originate in Western philosophies and ideals which are then propagated, if not also imposed, upon the rest of the world. Consider sustainability, for example: problems of sustainability originate in the Global North and yet the North today purports to educate the rest of the world on how to be sustainable. Dann and Hanschmann (2012: 126) talk about 
the creation of terms, concepts, ideas, forms and criteria-which are supposedly universal, but might also be seen as particularistic due to their Western bias - and the almost inevitably ensuing "realization" of the deficiencies of non-Western countries. For this reason, the question of one's own situatedness and the consideration of non-Western perspectives assume particular importance.

Indeed, it is important to acknowledge the fact that many popular business ethics and management frameworks reflect not the truth but a specific cultural/historic vantage point.

Bruni and Zamagni (2016) suggest that all these models and frameworks originate from a Western, primarily Anglo-Scottish philosophy of economics that assumes rational, self-interested, discrete, and autonomous agents. According to such an anthropology, competition between actors must necessarily occur in the marketplace, and so the ethics models and frameworks mentioned above aim to mitigate against the ill effects of extreme competition and bolster collaborative thinking at the micro and meso levels of analysis. Indeed, Arnett and Hunt have argued, on a broader scale, that commitment to deontological moral theory in business serves to reduce irrationally competitive behaviors (2002). Thus, while the objective of theories that deploy these models and frameworks is often to incorporate businesses into a web of interconnected interests by moving them away from narrow self-interest, such may remain limited if their approaches overly patronize and emphasize Western thinking, the neoclassical worldview, and the anthropology that undergirds it.

The discipline of business ethics, however, has served to stretch and challenge the neoclassical worldview with critiques of the economic paradigm itself as well as through the incorporation of numerous theories (Chan, 2008; Koehn, 1999; Forsyth, O'boyle, \& McDaniel, 2008; Khera, 2001). Lynn Stout, for instance, has pointed out that "the efficient market tenet has been largely discredited both empirically and theoretically" (Stout, 2013: 203); indeed, most theorists no longer confuse share price with company value. She has argued extensively against the shareholder value myth of corporations on legal, economic, and empirical grounds, placing greater emphasis on a company's long-term investors with the idea that tensions between them and other stakeholders dissolve with an expanded time horizon (Stout, 2012). 
Sandel (2013) has gone even further, critiquing the economism that undergirds the contemporary predominance of neoclassical economics which purports to be value neutral. He has argued that economics is a deeply normative enterprise, that the application of market norms and framing not only potentially corrupts goods by changing their nature but also reduces love and altruism in society by presuming the latter to be scarce resources (2013). Amartya Sen has likewise argued that economics is an ethically laden discipline, and has emphasized the role that values have played in many Asian economies over the ages (Sen, 1993). Giovanola (2009), having built even further upon Aristotelian virtue ethics and Sen's capabilities approach, invites us to rethink for more ethical ends the anthropological assumptions underlying economics. She highlights the potential for respect of diversity (437-439).

The field of business ethics, however, does not go far enough as its scope of research remains insufficiently diverse. Many articles focus on a distinct region of the world and often compare that region to the so-called West. Critical or postcolonial theories are underrepresented, and the field defaults to centering Western philosophies, thereby creating a vantage point that serves to uphold colonial discourses that assign epistemic privilege and priority to European-originated ideas and thinking. The presumed superiority of Western generated solutions to global problems must be decolonized. Our solution demands decolonization on multiple levels and focuses on indigenization, where ideas and strategies are driven by indigenous participants utilizing their own philosophies.

Critical management studies have offered numerous critiques of management and business ethics frameworks and models that purport to solve global problems. S. B. Banerjee has been a leading figure in this field, so let us focus on his critiques as paradigmatic. Banerjee (2018) draws upon the Environmental Justice Atlas (EJOLT, n.d.) to reveal how extractive industries in Asia, Africa, Australia, and the Americas adversely impact communities who end up reaping much of the harm and little of the gain from these business projects. Due to this accumulation of environmental and social damage, he concludes that mining, forestry, dams, transportation, fracking, drilling, exploration, and waste management remain to be unsustainable and unjust practices under current patterns of coloniality. Banerjee states: 


\begin{abstract}
The question of why the industry finds itself in conflict with the communities in which it operates [mostly in the Global South] despite its stakeholder engagement[, ethical business practices,] and CSR activities has not been satisfactorily addressed in the literature. (2018: 797-798)
\end{abstract}

Banerjee (2011b) has also connected extractive industries to the notion of the "development state" which was produced by power arrangements inherited from the colonial period. He has exposed how CSR operates to maintain and reinforce other colonial configurations of power (Banerjee, 2008) and conducted parallel critiques of sustainability (Banerjee, 2011a).

\title{
TOWARD A DECOLONIZING PERSPECTIVE
}

A central tenet of this study is the notion that global justice and sustainability problems will remain unsolved as long as solutions are driven from a single vantage point-that of the Global North. Dobers and Halme (2009: 246) point to this tendency and limitation by stating that "so far the CSR discussion has been dominated by US and EU perspectives whereas incorporating developing countries' perspectives should reflect the experiences 'from the ground' in the Global South." To this need of the time, we develop here a theory of Global Collaborative Advantage (GCA) as a means of rectifying the lacunae in existing scholarly approaches as well as of decolonizing scholarly methodologies. The model serves a pragmatic objective of shifting mindsets and centering marginalized voices to bring about authentic collaborative efforts, led by the voices of the Global South, to address global justice issues.

GCA offers a model for business organizations of relational exchange in markets that go beyond existing transactional models. In this sense, it builds on prevailing trends in business ethics and management research, working within these fields while striving for greater incorporation of diverse sources of wisdom (both classical and contemporary) from across the globe. Our model thus seeks to be more comprehensive and inclusive without centering the West, Global North, or United States. To that end, we draw inspiration from the field of critical management studies (Jack, Westwood, Srinivas, \& Sardar, 2011; Faria, 2013; van der Linde, 2016), postcolonial theories of organizations (Prasad, 2003; Banerjee, 2008, 2011a, 2011b), and decoloniality in international relations (Tickner, 2016; Mignolo, 2000) as well as contribute to the scholarly space created by several scholars in these areas who 
strive to critique and expand the field of business ethics (Khan \& Naguib, 2019; Jammulamadaka, 2015; Murove, 2005; Hall, 2001).

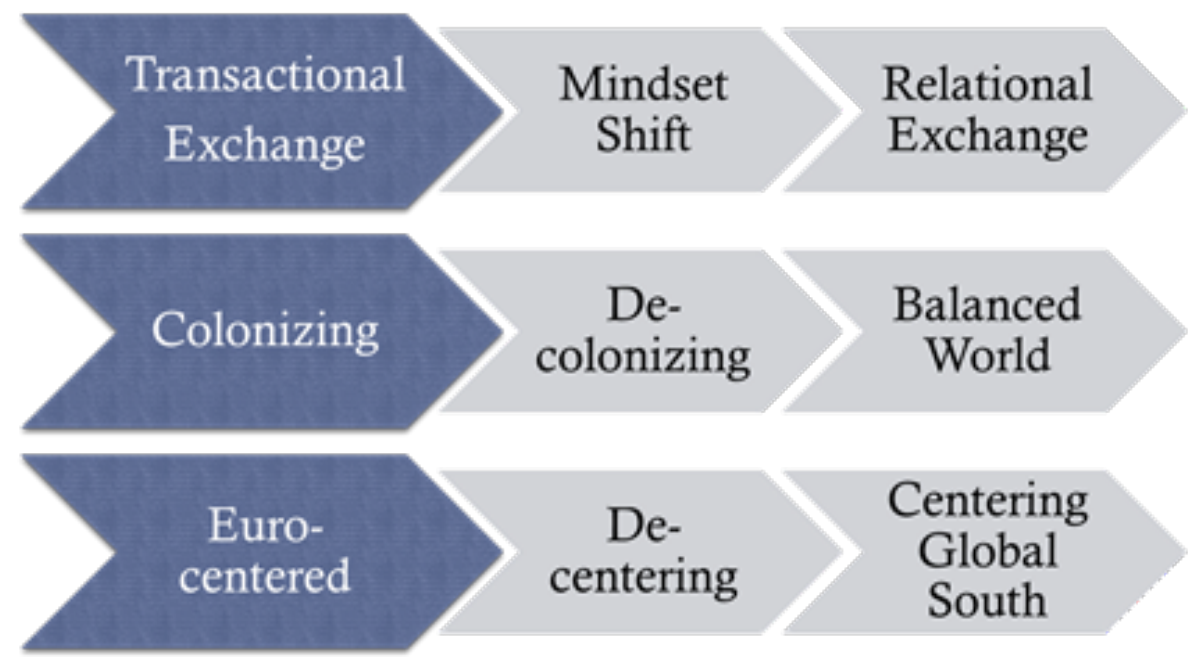

Figure 1: Transformative Work to Which the GCA Aspires

In what follows, we will paint a picture of the existing neocolonial reality as it is perceived by critics from the Global South before seeing how critical perspectives on these larger actors and context help to evaluate business ethics from a different vantage point.

\section{DECOLONIZING PERSPECTIVES ON THE GLOBAL POLITICAL-ECONOMY}

Numerous models, frameworks, and theories, while aiming to care about the problems of the Global South, have originated from a Eurocentric mindset in economically stable regions. The North views the South mainly as underprivileged, suffering from unstable economies and rampant corruption. Yet many in the South question why and for whose advantage these models and theories are crafted in the first place (Banerjee, 2008). Such frameworks are often viewed skeptically as forms of external political meddling and as reminiscent of colonial times (Banerjee, 2008). In fact, we see that many of them may even support, perhaps inadvertently, further exploitation and coloniality, naively envisioned as they were by those still seated in ivory towers. 
Let us take a moment to consider the broader global political-economic context, the domain in which business ethics, CSR, and their attendant models and frameworks operate. The activities and operations of a number of interstate actors, which emerged as the official colonial system collapsed at the end of the Second World War, serve as an important backdrop to international commerce and the activities of MNCs and TNCs. Yet the postcolonial era saw the continuation, out from the ashes of colonialism, of those same structures of power and oppression through insidious systems that came to be regarded by many as a form of neocolonialism. The United Nations, for example, is headquartered in the heart of the most modern city in the world-New York-from which it continues to generate frameworks and models to prevent or end wars, serve the poor, provide healthcare to the underinsured, feed the hungry, educate people, and democratize nations, to name a few. Why, then, should such an organization be stationed in one of the wealthiest cities in the world? Why should it not be in the poorest of the poorest instead, so as to be directly influenced by the smell, feel, sound, sight, and life lived by those whom they have targeted to "fix" and to help? Hanson has likewise made similar suggestions:

\footnotetext{
Where the seats of power are located matters.... Most of the world is nonWestern.... So why not move the United Nations to Haiti, Libya, or Uganda? The transference would do wonders for any underdeveloped country, financially, culturally, or psychologically. U.N. officials without easy access to Westernized media and the high life might instead have more time to concentrate on global problems such as hunger, disease, and violence.... (2018)
}

Such a relocation would involve an authentic participatory approach, for as matters stand, the interests, perspectives, priorities, and knowledge systems of the Global North remain centered, to the detriment of the South.

The same is the case with both the World Bank and International Monetary Fund (IMF), whose lending practices may be comparable to potentially predatory behaviors that already prevail in the Global North. In prepared remarks during the field hearing on payday lending, director of the Consumer Financial Protection Bureau (CFPB) Richard Cordray said that "consumers need credit that helps them, not harms them. If the lender's success depends on the borrower failing, market dynamics are not functioning properly" (2015). Such a critique may also be applied to the World Bank's and IMF's practice of trapping nations for generations just so 
the latter will have to pay high interest on development loans. The proceeds of these loans, moreover, often end up with corrupt politicians, and the funds are spent on infrastructure that tends to benefit TNCs in what seems like a form of neocolonialism wielded by former colonial powers instead of on building human capital (Perkins, 2008, 2016). IMF loans as such may have served true value after World War II but only for the benefit of Western nations; indeed, it is arguable that no country from the Global South has actually received any real or lasting benefit from such loans in recent decades (Perkins, 2016; Dreher, 2006; Easterly, 2005; Vaubel, 1983; Thacker, 1999).

Perkins (2008) argues that the structures of the World Bank and IMF suggest bias and a power imbalance. The president of the World Bank is always appointed by the U.S. president while the E.U. appoints the IMF head (Perkins, 2008: 3). Eight of the 24 directors on the IMF board represent the G8 countries, including the U.S., U.K., China, Russia, Japan, Saudi Arabia, France, and Germany, while the remaining 16 represent the rest of the world's 184 states. The U.S., furthermore, may exercise veto power on major decisions. Further critiques of these institutions have also been discussed by various authors (Stiglitz, 2003; Ellerman, 2006; Perkins, 2008; Standing, 2000; Peet, 2009; Bello, Cunningham, \& Rau, 1994).

A broad movement has also sprung up alongside predatory lending practices to offer development assistance through charitable giving (i.e., development aid). Dambisa Moyo (2010), however, states that the most aid-dependent countries have exhibited an average annual growth rate of negative $0.02 \%$. $70-80 \%$ of Africans, for instance, are living in poverty today, at a time when aid models are dominant everywhere and celebrities glamorize the industry, compared to only $10 \%$ in 1970 (Hilary, 2010; Moyo, 2010; Richey \& Ponte, 2008). Moyo further points out that aid and corruption are inextricably linked, and that aid models may have worsened the quality of leadership abroad (Banerjee \& Duflo, 2011; Moyo, 2010). She argues that while aid is presented as a gift of free money, countries continually weaken while the aid industry flourishes for the benefit of those in the Global North. Indeed, an exceptionally large majority of aid comes with many strings attached. 


\section{DECOLONIZING PERSPECTIVES ON BUSINESS ETHICS AND CSR-RELATED FRAMEWORKS}

We can see clearly the limitations of market-based frameworks and ideas such as CSR, CC, TBL, etc. These Euro-originated philosophies and models that stem from the narrow conceptions of homo economicus may have a certain degree of benefits and be well-intentioned but have failed to produce needed change thus far. They operate within the domain of a fundamentally problematic system of oppression and ultimately serve to remediate only slightly the harms done by this system while leaving the system itself unchallenged. Such frameworks presuppose a flawed global economic backdrop of business activity, serving indirectly to prop up a system that works to the advantages of those who develop and propagate these ideas. Indeed, these business ethics and CSR-related frameworks are not the solution but part of the ultimate problem.

Corporations propagate and support such superficial solutions through their utilization of these frameworks and models. According to Jabbar and Obstfeld, for example, a 2014 study by Gilens and Page found that the most "politically active companies in the United States spent $\$ 5.8$ billion on lobbying and campaign contributions" over the last five years (2010-2014) to obtain trillions of dollars in subsidies and other benefits at the expense of American taxpayers (Abdul-Jabbar \& Obstfeld, 2016: 18). They concluded that American politics is best characterized by "economic-elite domination" and "biased pluralism" (Gilens \& Page, 2014). Such findings point to the power of corporate businesses in the U.S. and reveal the dark side of the corporation as a political actor. CSR, CC, and other related business ethics frameworks and models may thus very well serve to divert attention away from these and a myriad of other corporate misdeeds, and ease the public into being comfortable with heightened corporate power vis-à-vis the nation state (Ludescher, 2009).

All this is a concern about how markets are structured and manipulated to serve the private interests of powerful actors, not a critique of market mechanisms per se. The term "capitalism" is troubling not because of the commonly critiqued values of free enterprise, property rights, or the price mechanism of resource allocation but because it is a system of political economy under the guise of the notion of capital (which is an economic construct to denote the capacity for wealth creation). Capital itself has value, yet it ought not to reign supreme as it is not human nor does it represent the most fundamentally relevant human values. Furthermore, the 
artificial construction of the economic agent in the discipline of economics and worldview of capitalism as a rationally self-interested wealth aggrandizer fails to represent how most of humanity (including people from Euro-originated societies) actually think, value, and act in the real world. Such a critique of capitalism is not new, nor is it alien to the field of business ethics, yet it must be delineated so as to avoid confusing our decolonial critique of capitalism with naïve Marxism.

What remains at issue in business ethics and CSR-related frameworks is the reluctance to challenge both the way the whole global system owes its debts to colonialism and imperialism and how that system of neocolonialism continues to advance the interests of the Global North and other beneficiaries of the colonial endeavor. For these fields to grow and evolve, a postcolonial mindset must be more fully incorporated to critique the system itself before determining what the responsibilities of businesses are within that unjust system.

Many business ethicists, moreover, at least in the United States, Canada, and Europe, have hailed historically from the discipline of philosophy. Thus, when faculty with PhDs in philosophy began working in the schools of business and economics, they brought their mainly Euro-originated theories into their studies of business responsibilities and market structures. These philosophers in theory have worked to make business and economics more ethical, advocating that MNCs and TNCs adhere to higher standards closer to those of their home countries when doing business abroad. As Hall (2001) has pointed out, however, many scholars presuppose a sense of intellectual superiority about these moral theories and the economic realities of the Global North in ways that fail to reckon with the impending reality of economic ascendancy in other parts of the globe, such as in India and China.

Many of the U.S. business and economics schools in which philosophers reside are quite diverse both ethnically and nationally, yet the field of philosophy from which these ethicists originate is far from being such. Arguably one of the whitest disciplines in the entire academe, philosophy was originally conceptualized in ancient Athens as its Greek name indicates, and only recently has any concerted effort been made to diversify its ranks and its self-conception. The American Philosophical Association (APA), for example, reports that the body of its members in 2017 was 75.97\% white/Caucasian (compared to whites who comprise 61.3\% of the U.S. population), $2.6 \%$ black/African-American (compared to $13.3 \%$ in the 
U.S.), and 4.79\% Hispanic/Latino (compared to 17.8\% in the U.S.). The proportion of members of other racial/ethnic categories was more comparable to that in the U.S. population, with Asian APA members (6.78\%) being slightly higher than the U.S. percentage of 5.7\% (see Appendix A for further details). This last difference may be explained by the increasing presence of Asian philosophies in the curriculum, although this is related partly to the interest which the white population of the U.S. has for such philosophies. At any rate, the figures are not surprising to anyone who has spent considerable time in the academic discipline, though it should be noted that not all philosophers are members of the APA (sometimes for financial reasons). Moreover, while there is no data available from the Society for Business Ethics on the racial identifications of its members or percentage of those who earned degrees in philosophy, it is commonly accepted that most academic business ethicists in the U.S. are philosophers and that most are white males. Indeed, a recent look at submissions to the Society of Business Ethics conference as sorted by country also reveals a heavy preponderance of U.S. and European nations (see Appendix B for further details). As such, while residency demographics are not approximations of race in most cases, they do reveal an overall sense of Euro-dominance in business ethics studies. Yet most of the world's population about whom these philosophers talk or "care about" belong to the South, people who may not care for or even trust these voices and frameworks.

\section{GLOBAL COLLABORATIVE ADVANTAGE MODEL}

If academics, scholars, and practitioners truly want to make a difference, there should be an authentic seeking out of the creation of a space where all seven billion of the planet's inhabitants are able to live out all the tenets of Maslow's hierarchy of needs: physiological, safety, social belonging, esteem, self-actualization, and self-transcendence (McLeod, 2018). Indeed, the first four needs at minimum must be met, but our current development picture far from correctly approximates the costs of those basic human needs given that three billion people live under $\$ 2$ a day while $20 \%$ of the North consumes $80 \%$ of the world's resources. We thus propose the concept of Global Collaborative Advantage (GCA) as a means of orienting all of humanity toward the real needs of all its members. 
Our proposal for GCA should not be confused with a call for more aid or CSR; rather, it calls for business ethics that are founded on multi-sectoral collaboration to change practices and processes into ones that could taper or even eliminate aid and other types of foreign interference. GCA is not just a new business ethics or management fad to replace one trendy slogan with a new one that businesses can market and scholars can analyze. We are calling for a shift in mindset that will lead to entirely new habits of thought and action at all levels. GCA requires a transformational approach that can be manifested in a variety of ways and places by different institutions. As such, we focus here on applications for business practitioners and scholars.

The proposal will detail some potential changes in thinking as well as in practices that support the strengthening of communal autonomies across the globe, all aiming for the full actualization of all human needs. Given that such a mindset shift will proceed through multiple stages and steps, we propose 1) the incorporation of multiple perspectives, especially those from the Global South, in scholarship and practice, 2) a truth and reconciliation process, 3) the development and metamorphosis of global institutions for GCA, and 4) a new research agenda for educators and scholars. Each of these stages may proceed in tandem as the cultivation of global institutions may, for instance, support both a truth and reconciliation process and academic work. Truth and reconciliation can likewise motivate and animate the trust needed in cultivating global institutions and academic work. Finally, academics can study and teach about both truth and reconciliation and global institutions.

\section{Incorporation of Multiple Perspectives}

It is critical that scholars and practitioners worldwide understand local and indigenous knowledge and wisdom and incorporate such into their writings and decision-making. Even though generalizations are always problematic, a few key differences in worldview between South and North can be discerned. Perspectives from the Global South tend to emphasize trust, long-term relationships, and sharing in contrast with the Global North which tends to emphasize a transient, give-andtake, win-or-lose, calculated, and methodical approach to business. While we do not deny outright the value of the latter, it certainly has not lacked the opportunity to impose itself on the former. We therefore call for more attention to be given to those perspectives from the Global South. 
Murove (2005), for example, argues that the inclusion of African indigenous values in business would give the latter a new image in communities. Indeed, Dandala (1996: 80) describes the African ethic of $u b u n t u$ as that which lies at the core of human relationships, innovation, and productivity. It emphasizes relationality, meaning we as human beings are inseparable and affect each other, and embraces the concepts of belonging for its members and of being people-friendly toward other stakeholders. Ubuntu should therefore be incorporated into contemporary business practices.

Another example is the practice of the Minga, or community work, that the Kichwa people of Sarayaku engage in regularly. Foreigners visiting their community to learn about their cosmology, lifeways, and ongoing struggles against oil extraction are often invited to engage in the practice shortly after their arrival. The Kichwa partner with NGOs like Amazon Watch who occasionally arrange for such journeys, offering an economic alternative to the eco-tourism other communities rely upon for survival in the face of ongoing threats posed by the petroleum industry.

One of the authors of this article belongs to the tribal area of Pakistan called Waziristan. Lacking a police force until now, the people of Waziristan govern themselves through the Jirga system, which is a participatory approach of reconciling differences and working toward solutions and progress. As a result of this ancient system of self-governance, not a single rape or theft has occurred in the recorded history of this civilization. The goal is to solve the problem at its inception instead of waiting for issues to progress to the point of violence. This tiny civilization, moreover, was the only place in British-India that could not be conquered (Caroe, 1958), which primarily means that the community of Waziristan remained largely uninfluenced and unchanged by Eurocentric ethics and thinking.

We therefore encourage all institutions of privilege and power, from universities to the World Bank, to make a special effort to reach out to and invite speakers, writers, teachers, and leaders whose worldviews are underrepresented. Indeed, some of the processes that will support broader incorporation of worldviews can occur through truth and reconciliation, the next stage of GCA. 


\section{Truth and Reconciliation}

Before proceeding further with GCA, we propose a truth and reconciliation process among business leaders, politicians, employees, small business owners, local activists, and local communities. Such a process must begin with full disclosure and truth regarding historical information that is relevant to justice. Then, once all concerned parties in a given context gain an adequate understanding of where they stand vis-à-vis histories, they can begin to assume responsibility for the beneficiary roles that they play, whether for good or for ill. We therefore suggest that societies (historically colonialist and imperialistic-minded nations in particular) must first admit both the wrongs that were committed in the past and the ills that are still being committed to this day under the rubric of new slogans (e.g., terrorism, etc.) and then humbly ask how to move forward and learn from their mistakes. It is a difficult process and practice, and an impossible one unless social activists, educators, scholars, students, and business managers in the Global North admit that the divisive and unethical ways of doing business (win-lose) in the past are unsustainable in the foreseeable future. People around the world are becoming wiser through education and social media and gaining voice slowly but surely. It is imperative, therefore, to think in new ways of collaboration with a win-win mindset.

It is important that underrepresented leaders from the Global South who operate at the local level take the lead in initiating such a process, drawing upon help that is given only when requested. Local NGOs, for example, might partner with global ones to host forums for discussion and relationship building that will emphasize friendship creation through shared work projects, storytelling, creative endeavors, cultural experiences, and other practices that are derived from their respective contexts and imaginative spaces. Such apparently non-business activities may open up representatives from institutions in the Global North to new ideas and perspectives as well as create a sense of shared meaning and vulnerability that might invite a greater capacity for apology and rectification. There is no doubt that the challenges will prove arduous and not lead to universal success in the short term, yet processes must be attempted and small gains celebrated. Starting small is recommended, and with participants that already express an interest in such a process, before utilizing social media exposure to spread awareness and increase motivation elsewhere. Awareness will, ideally, reach even world governing institutions like the WB or IMF, or governments of developed countries, prompting reflection and reconsideration on their part, although such a broad grassroots 
movement may already work to extricate the Global South from the perceived need to maintain dependency on such institutions.

The processes of post-apartheid in South Africa could also serve as inspirational examples, although these should not be viewed in an "othering" way as if the U.S. and some of its citizens were not in desperate need of making reparations to multiple groups. The initial inhabitants of settler colonization still call out for justice, above and beyond the obvious need to rectify the injustices of the transatlantic slave trade and Jim Crow era of legality. There were 11 million Native Americans in North America before the land was colonized; today there are only one million of them. Indeed, the rest of the U.S. population has increased threefold while the Native American population has receded greatly. It is similarly the case with Australia's aborigines. As such, while the topic of reparations remains highly controversial, mired with debates about responsibility attribution for the wrongs of dead forbears, a minimal account of collective responsibility and beneficiary relation to systems of oppression would suggest that some form of reparations do need to be made. We therefore support efforts to continue that conversation for the sake of reparative justice.

There is also a need to develop a truth and reconciliation process between governments, local government representatives, community leaders, relevant MNC and TNC managers, civil society leaders, and other key global stakeholders who are typically hidden from view on the balance sheets. Such a departure differs radically from existing business ethics and CSR-related frameworks in that the moral superiority of enterprises originating from the Global North is not its default presumption. The starting position, rather, is a decolonial vantage point emerging from the centuries old death project known as European imperialism that recognizes the global-economic system and the dominant players that benefit from it (Suárez-Krabbe, 2016). Indeed, whether or not powerful and wealthy business elites directly undertook any individually harmful actions is irrelevant to the reality of their reaping the bounty from centuries of systemic plundering, extractions, and oppression. These elites, along with other well-off stakeholders (consisting mostly of Americans, Canadians, Europeans, and Japanese as well as elites in the Global South), need to recognize their roles in this system of oppression. They need to apologize and seek to make amends, through both material and immaterial means, in response to the requests of those on the underside of oppression. Business 
ethics, corporate social responsibility, etc. in this sense entail, first and foremost, a rectification of historical injustice. Such a truth and reconciliation process should lead to a truly participatory approach which will move the world toward global collaborative advantage.

It is important to remember, moreover, that the oppressor can also benefit just as well as the oppressed from such a process. In the closing paragraphs of his autobiography Long Walk to Freedom, Nelson Mandela writes of his 27 years as a political prisoner:

\begin{abstract}
It was during those long and lonely years that my hunger for the freedom of my own people became a hunger for the freedom of all people, white and black. I knew as well as I knew anything that the oppressor must be liberated just as surely as the oppressed. A man who takes away another man's freedom is a prisoner of hatred, he is locked behind the bars of prejudice and narrowmindedness. I am not truly free if I am taking away someone else's freedom, just as surely as I am not free when my freedom is taken from me. The oppressed and the oppressor alike are robbed of their humanity. (Mandela, quoted in Daloz, Keen, Keen, \& Parks, 1996: 78)
\end{abstract}

Ultimately, we need to suspend our assumptions of superiority and inferiority, eradicate these internalized complexes, and cultivate trust that heals the violence. Mignolo (2007) has theorized such an approach under the auspices of the decolonization of knowledge systems, which in themselves are also systems of power. Considering the case of the Zapatistas, he argues that we need to move from a model of inclusion to one of interculturality that acknowledges the plurality of "worlds" constituted by various cosmologies and epistemologies that run counter to the dominant neocolonial narratives (Mignolo, 2007: 143). Possibly one of the most insidious means by which powerful global structures of injustice continue to be propagated, a sense of epistemic superiority constitutes a key barrier to authentic human engagement between peoples across the globe. Civility, humility, decency, and respect for each other should be the universal values driving the truth and reconciliation process.

The dialogue must begin therefore with what wrongs were done and how these resulted in hate and mistrust across the world. There can be no trust or the beginning of moral respect between peoples until some of the old wounds begin to heal. Truth, reconciliation, and the deconstruction of knowledge systems built on assumptions of superiority must precede collaborative projects for which trust is 
essential. Double loop learning (Argyris, 1977) can support this process at a tangible level where questions can be asked from the other side of the aisle and a generative and equal participatory dialogue for the reconstruction of global society will result. This in turn will lead to an opening of minds and the possibility of establishing a space of trust.

- Humility - Respect

Participatory Process
Suspend

Complexes

- Superiority

- Inferiority

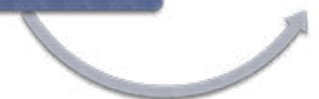

Figure 2: Processes Involved in Truth and Reconciliation

The Constellation of Global Collaborative Institutes

Another stage of GCA will involve the creation and constellation of collaborative institutions that will be very different from what we see today. People representing different countries, mesmerized and influenced by the splendor of the World Bank, IMF, and United Nations buildings, are prompted to obedience rather than to challenge current short-term, one-way solutions which are not only mostly expensive but also misguided. We need to have GCA as a physical structure (perhaps as a collection of places rather than as a shiny, towering building) that is situated in the poorest countries and led by people who are elected by the locals based on their wisdom, traditions, trustworthiness, integrity, and care for others. There could be learning and doing institutes, for instance, to identify problems and come up with local solutions. Indeed, it is recommended that the learning and action dimensions of GCA should 1) reside in developing/emerging economies and 2) be simple, sustainable, and low cost structures, with 200 of these, each representing a different country, to decrease the superiority or inferiority complexes to which all 
participants are currently exposed. Bureaucrats and technocrats from each country can thus visit each other's hut/building and openly negotiate investment contracts without fear or intimidation. Laws should be passed in advance, however, with regard to preventing fraud, deception, and harm while incentivizing collaborative advantage, the advancement of global human prosperity through multiple and inclusive perspectives, and working toward "one world, one people."

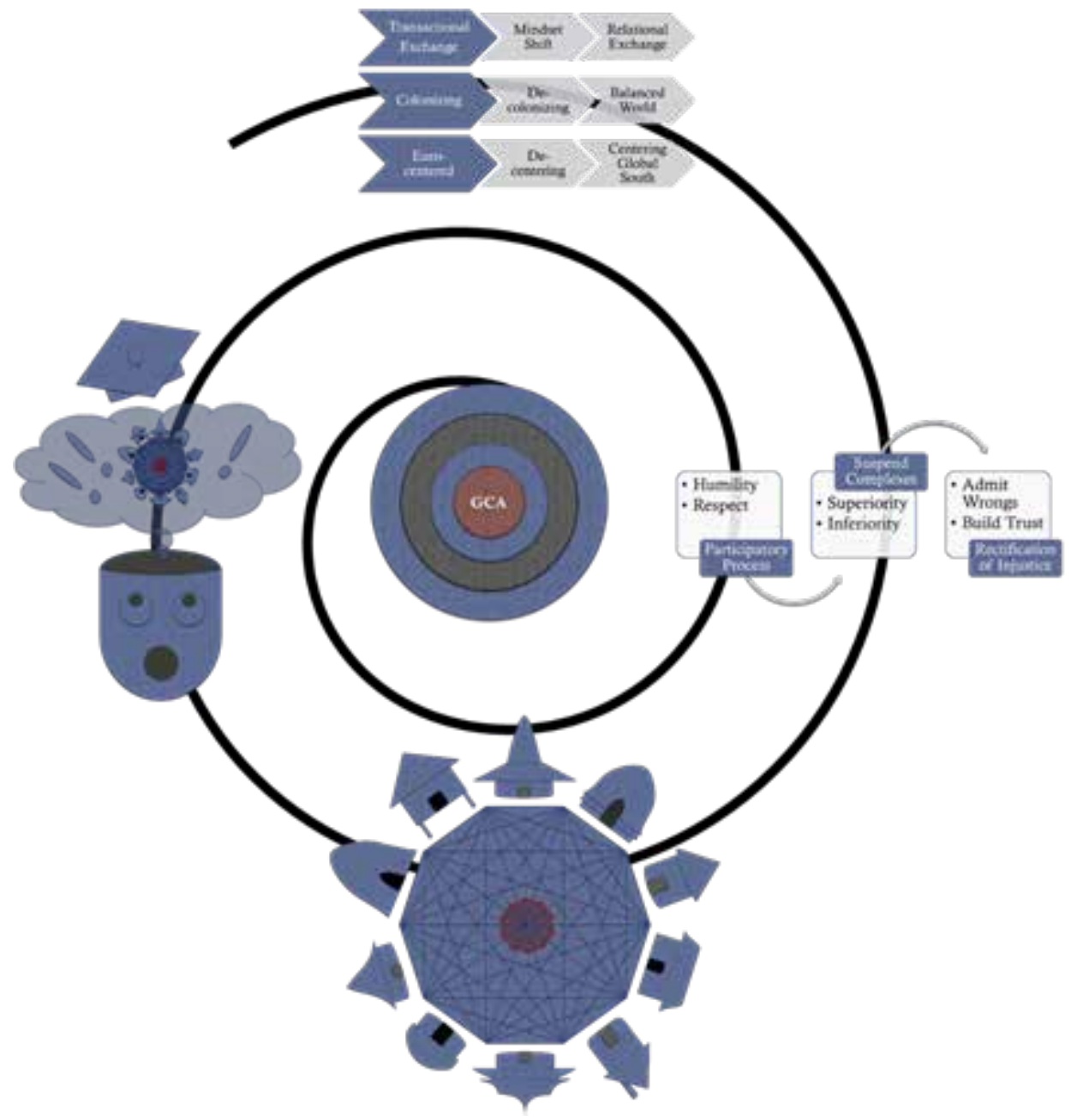

Figure 3: Summary of the GCA Model 


\section{A Research Agenda for Scholars and Educators}

Finally, and of most relevance to the academic readership, educators and scholars need to embody GCA in their teaching and research. Some research questions that can inspire scholarly studies related to GCA include the following: How do cultural, religious, and philosophical presuppositions from different places inform actual business practice, and how does this translate into beneficial global business practices? How can these worldviews serve to inform further the regions from which they hail as well as integrate with and inform thinking in other places without suffering from the power dynamics of unjust cultural appropriation? How can common ground across diverse perspectives be identified without sacrificing plurality or centering or implicitly catering to a specific worldview? How can the wisdom of Global South worldviews serve a decolonial project that enables forms of our truth and reconciliation process to unfold in unique, novel, and ultimately practical ways? How can we cultivate an abundance mindset that brings about winwin solutions for all stakeholders on the planet?

\section{CONCLUSION}

The idea of Global Collaborative Advantage (GCA) is that ethics should not be the prerogative of the North and that civilizations of the Global South should inform the world with wisdom that can help in progress while negating the many ills spawned by the capitalistic Eurocentric mindset. The current mindset and nature of work, scholarly or otherwise, must first be decolonized. The prevalent ethical business frameworks and models, which have been derived from Eurocentric theories and philosophies which the Global North has enforced upon the Global South, must then be deconstructed and replaced, this time with philosophies and ethics that are not generated solely by and in the North but also derived from the rich yet untapped wisdoms and ancient histories of the South.

These voices, no matter how diverse or divergent they may be, have strong and powerful messages to be incorporated for the sake of GCA. This model takes a macro level approach to integrate worldviews while allowing for the translation of derived and aggregated information to be applied at the meso and micro levels of business. Indeed, management for global sustainability requires constant attention to the most vulnerable stakeholders and the global problems that continue to beset 
them. GCA, therefore, is ultimately a call for scholars to reconsider the relevance of what they write and produce. It offers one way to bolster collaboration and openmindedness through an approach that de-centers the loudest voice of the North and centers the unheard voices of the South, vocalizing their ethics, culture, wisdoms, and traditions.

\section{REFERENCES}

Abdul-Jabbar, K., \& Obstfeld, R. 2016. Writings on the wall: Searching for a new equality beyond black and white. New York: Liberty Street/Time Inc.

Argyris, C. 1977. Double loop learning in organizations. Harvard Business Review, 55(5): 115-125.

Arnett, D. B., \& Hunt, S. D. 2002. Competitive irrationality: The influence of moral philosophy. Business Ethics Quarterly, 12(3): 279-303.

Arthaud-Day, M. L. 2005. Transnational corporate social responsibility: A tridimensional approach to international CSR research. Business Ethics Quarterly, 15(1): 1-22.

Banerjee, A., \& Duflo, E. 2011. Poor economics: A radical rethinking of the way to fight global poverty (1st ed.). New York: PublicAffairs.

Banerjee, S. B. 2008. Corporate social responsibility: The good, the bad and the ugly. Critical Sociology, 34(1): 51-79.

Banerjee, S. B. 2011a. Embedding sustainability across the organization: A critical perspective. Academy of Management Learning \& Education, 10(4): 719-731.

Banerjee, S. B. 2011b. Voices of the governed: Towards a theory of the translocal. Organization, 18(3): 323-344.

Banerjee, S. B. 2018. Transnational power and translocal governance: The politics of corporate responsibility. Human Relations, 71(6): 796-821. 
Bello, W., Cunningham, S., \& Rau, B. 1994. Dark victory: The United States, structural adjustment, and global poverty. London: Pluto / Oakland, CA: Food First / Amsterdam: Transnational Institute.

Bruni, L., \& Zamagni, S. 2016. Civil economy: Another idea of the market. Newcastle: Agenda Publishing.

Caroe, O. 1958. The Pathans: 550 B.C.-A.D. 1957. London/New York: Macmillan/ St. Martin's Press.

Chan, G. K. Y. 2008. The relevance and value of Confucianism in contemporary business ethics. Journal of Business Ethics, 77: 347-360.

Cordray, R. 2015. Prepared remarks of CFPB Director Richard Cordray at the field hearing on payday lending. Consumer Financial Protection Bureau. Available at https://www.consumerfinance.gov/about-us/newsroom/prepared-remarks-ofcfpb-director-richard-cordray-at-the-field-hearing-on-payday-lending/.

Daloz, L. A. P., Keen, C. H., Keen, J. P., \& Parks, S. D. 1996. Common fire: Leading lives of commitment in a complex world. Boston, MA: Beacon Press.

Dandala, H. M. 1996. Cows never die: Embracing African cosmology in the process of economic growth. In R. Lessem \& B. Nussbaum (Eds.), Sawubona Africa: Embracing four worlds in South African management: 69-85. Sandton, South Africa: Zebra Press.

Dann, P., \& Hanschmann, F. 2012. Post-colonial theories and law. Law and Politics in Africa, Asia, and Latin America, 45(2): 123-127.

Donaldson, T., \& Dunfee, T. W. 1994. Toward a unified conception of business ethics: Integrative social contracts theory. Academy of Management Review, 19(2): $252-284$.

Dobers, P., \& Halme, M. 2009. Corporate social responsibility and developing countries. Corporate Social Responsibility and Environmental Management, 16(5): 237-249. 
Dreher, A. 2006. IMF and economic growth: The effects of programs, loans, and compliance with conditionality. World Development, 34(5): 769-788.

Duffin, E. 2019. Percentage distribution of population in the United States in 2016 and 2060, by race and Hispanic origin. Statista. Available at https:// www.statista.com/statistics/270272/percentage-of-us-population-by-ethnicities/ (accessed May 26, 2017).

Easterly, W. 2005. What did structural adjustment adjust? The association of policies and growth with repeated IMF and World Bank adjustment loans. Journal of Development Economics, 76(1): 1-22.

EJOLT [Environmental Justice Organizations, Liabilities and Trade]. n.d. Mapping environmental justice. Available at http://www.ejolt.org/.

Elkington, J. 1994. Towards the sustainable corporation: Win-win-win business strategies for sustainable development. California Management Review, 36(2): 90-100.

Ellerman, D. 2006. Helping people help themselves: From the World Bank to an alternative philosophy of development assistance. Ann Arbor: University of Michigan Press.

Faria, A. 2013. Border thinking in action: Should critical management studies get anything done? In V. Malin, J. Murphy, \& M. Siltaoja (Eds.), Getting things done, Dialogues in critical management studies vol. 2: 277-300. Bingley, UK: Emerald.

Forsyth, D. R., O’boyle, E. H., \& McDaniel, M. A. 2008. East meets west: A metaanalytic investigation of cultural variations in idealism and relativism. Journal of Business Ethics, 83(4): 813-833.

Freeman, R. E. 1994. The politics of stakeholder theory: Some future directions. Business Ethics Quarterly, 4(4): 409-421.

Gilens, M., \& Page, B. 2014. Testing theories of American politics: Elites, interest groups, and average citizens. Perspectives on Politics, 12(3): 564-581. 
Giovanola, B. 2009. Re-thinking the anthropological and ethical foundation of economics and business: Human richness and capabilities enhancement. Journal of Business Ethics, 88(3): 431-444.

Glasbergen, P. 2011. Understanding partnerships for sustainable development analytically: The ladder of partnership activity as a methodological tool. Environmental Policy and Governance, 21(1): 1-13.

Hall, J. A. 2001. Confessions of a eurocentric. International Sociology, 16(3): 488-497.

Hanson, V. D. 2018. Why the UN should move headquarters out of New York. The Mercury News, Feb. 2. Available at https://www.mercurynews.com/2018/02/02/ hanson-why-un-should-move-headquarters-out-of-new-york/.

Hilary, J. 2010. Africa: Dead Aid and the return of neoliberalism. Race \& Class, 52(2): 79-84.

Hsieh, N. H. 2015. The social contract model of corporate purpose and responsibility. Business Ethics Quarterly, 25(4): 433-460.

Hussain, N., Rigoni, U., \& Orij, R. P. 2018. Corporate governance and sustainability performance: Analysis of triple bottom line performance. Journal of Business Ethics, 149(2): 411-432.

Jack, G., Westwood, R., Srinivas, N., \& Sardar, Z. 2011. Deepening, broadening and re-asserting a postcolonial interrogative space in organization studies. Organization, 18(3): 275-302.

Jammulamadaka, N. 2015. Responsibility for the third world factory: Limits of eurocentric CSR and making room for the state. Decision, 42(1): 71-82.

KFF [Kaiser Family Foundation]. n.d. Population distribution by race/ethnicity. Available at https://www.kff.org/other/state-indicator/distribution-by-raceeth nicity/?currentTimeframe=0\&sortModel=\%7B\%22 colId $\% 22: \% 22$ Location $\% 2$ 2,\%22sort\%22:\%22asc\%22\%7D (accessed May 26, 2018).

Khan, F. R., \& Naguib, R. 2019. Epistemic healing: A critical ethical response to epistemic violence in business ethics. Journal of Business Ethics, 156(1): 89-104. 
Khera, I. P. 2001. Business ethics East vs. West: Myths and realities. Journal of Business Ethics, 30(1): 29-39.

Kochan, T. A., \& Rubinstein, S. A. 2000. Toward a stakeholder theory of the firm: The Saturn partnership. Organization Science, 11(4): 367-386.

Koehn, D. 1999. What can Eastern philosophy teach us about business ethics? Journal of Business Ethics, 19(1): 71-79.

Lasker, R. D., Weiss, E. S., \& Miller, R. 2001. Partnership synergy: A practical framework for studying and strengthening the collaborative advantage. The Milbank Quarterly, 79(2): 197-205.

Logsdon, J. M., \& Wood, D. J. 2002. Business citizenship: From domestic to global level of analysis. Business Ethics Quarterly, 12(2): 155-187.

Ludescher, J. 2009. From corporate strategy to global justice. Harvard International Review, April 19.

Lyon, T., Delmas, M., Maxwell, J., Bansal, P., Chiroleu-Assouline, M., Crifo, P., Durand, R., Gond, J. P., King, A., Lenox, M., Toffel, M., Vogel, D., \& Wijen, F. 2018. CSR needs CPR: Corporate sustainability and politics. California Management Review, 60(4): 5-24.

Matten, D., \& Crane, A. 2005. Corporate citizenship: Toward an extended theoretical conceptualization. Academy of Management Review, 30(1): 166-179.

McLeod, S. A. 2018. Maslow's hierarchy of needs. Simplypsychology.org, May 21. Available at https://www.simplypsychology.org/maslow.html.

McWilliams, A., \& Siegel, D. 2001. Corporate social responsibility: A theory of the firm perspective. Academy of Management Review, 26(1): 117-127.

Michaelson, C. 2010. Revisiting the global business ethics question. Business Ethics Quarterly, 20(2): 237-251.

Mignolo, W. D. 2000. Local histories/global designs: Coloniality, subaltern knowledges, and border thinking. Princeton: Princeton University Press. 
Mignolo, W. D. 2007. The idea of Latin America. Oxford: Blackwell Publishing.

Moyo, D. 2010. Dead aid: Why aid is not working and how there is a better way for Africa. New York: Farrar, Straus and Giroux.

Murove, M. F. 2005. The voice from the periphery: Towards an African business ethics beyond the Western heritage: Economics. South African Journal of Economic and Management Sciences, 8(3): 339-347.

Norman, W., \& MacDonald, C. 2004. Getting to the bottom of "triple bottom line." Business Ethics Quarterly, 14(2): 243-262.

Peet, R. 2009. Unholy trinity: The IMF, World Bank, and WTO. London: Zed Books Ltd.

Perkins, J. 2008. The secret history of the American empire: The truth about economic hit men, jackals, and how to change the world. New York: Dutton/ Penguin Publishing.

Perkins, J. 2016. The new confessions of an economic hit man. Oakland: BerrettKoehler Publishers.

Pies, I., Hielscher, S., \& Beckmann, M. 2009. Moral commitments and the societal role of business: An ordonomic approach to corporate citizenship. Business Ethics Quarterly, 19(3): 375-401.

Prasad, A. 2003. The gaze of the other: Postcolonial theory and organizational analysis. In A. Prasad (Ed.), Postcolonial theory and organizational analysis: A critical engagement: 3-43. New York: Palgrave Macmillan.

Richey, L. A., \& Ponte, S. 2008. Better (Red) ${ }^{\mathrm{TM}}$ than dead? Celebrities, consumption and international aid. Third World Quarterly, 29(4): 711-729.

Sandel, M. J. 2013. Market reasoning as moral reasoning: Why economists should re-engage with political philosophy. Journal of Economic Perspectives, 27(4): 121-140. 
Scherer, A., \& Palazzo, G. (Eds.). 2008. Handbook of research on global corporate citizenship. Cheltenham, UK: Edward Elgar Publishing.

Scherer, A., Palazzo, G., \& Matten, D. 2014. The business firm as a political actor: A new theory of the firm for a globalized world. Business \& Society, 53(2): 143-156.

Sen, A. 1993. Does business ethics make economic sense? Business Ethics Quarterly, 3(1): 45-54.

Standing, G. 2000. Brave new words? A critique of Stiglitz's World Bank rethink. Development and Change, 31(4): 737-763.

Stiglitz, J. 2003. Globalization and its discontents. New York: Norton.

Stout, L. 2012. The shareholder value myth: How putting shareholders first harms investors, corporations, and the public. San Francisco, CA: Berrett-Koehler Publishers, Inc.

Stout, L. 2013. The toxic side effects of shareholder primacy. University of Pennsylvania Law Review, 161(7): 2003-2023.

Strudler, A. 2015. Normative business ethics in a global economy: New directions on Donaldsonian themes. Business Ethics Quarterly, 25(4): xvii-xxi.

Suárez-Krabbe, J. 2016. Race, rights, and rebels: Alternatives to human rights and development from the global south. London: Rowman \& Littlefield.

Thacker, S. C. 1999. The high politics of IMF lending. World Politics, 52(1): 38-75.

Tickner, J. A. 2016. Knowledge is power: Challenging IR's Eurocentric narrative. International Studies Review, 18(1): 157-159.

U.S. Census Bureau. n.d. QuickFacts: United States. Available at https://www.census. gov/quickfacts/fact/table/US/PST045216 (accessed May 26, 2018).

van der Linde, T. N. 2016. What is critical in critical management studies? In G. Goldman (Ed.), Critical management studies in the South African context: 31-58. Durbanville: AOSIS Ltd. 
Vaubel, R. 1983. The moral hazard of IMF lending. World Economy, 6(3): 291-304.

Wettstein, F. 2012. CSR and the debate on business and human rights: Bridging the great divide. Business Ethics Quarterly, 22(4): 739-770.

Windsor, D. 2004. The development of international business norms. Business Ethics Quarterly, 14(4): 729-754.

Acknowledgements. Figures and other research materials were developed and gathered by research associates Claudia Dominguez and Emily Tennyson.

\section{APPENDICES}

\begin{tabular}{|c|c|c|c|c|c|c|}
\hline Race/ethnicity & $\begin{array}{c}\text { APA } \\
\text { Members } \\
2015(\%)\end{array}$ & $\begin{array}{c}\text { Pop. in } \\
\text { USA } \\
2015(\%)\end{array}$ & $\begin{array}{c}\text { APA } \\
\text { Members } \\
2016(\%)\end{array}$ & $\begin{array}{c}\text { Pop. in } \\
\text { USA } \\
2016(\%)\end{array}$ & $\begin{array}{c}\text { APA } \\
\text { Members } \\
2017(\%)\end{array}$ & $\begin{array}{c}\text { Pop. in } \\
\text { USA } \\
2017(\%)\end{array}$ \\
\hline $\begin{array}{c}\text { American Indian / } \\
\text { Alaska Native }\end{array}$ & 0.7 & 0.73 & 0.79 & 1 & 1 & 1.3 \\
\hline Asian & 5.86 & 5.28 & 6.1 & 6 & 6.78 & 5.7 \\
\hline $\begin{array}{c}\text { Black/African } \\
\text { American }\end{array}$ & 3.92 & 12.38 & 2.84 & 12 & 2.6 & 13.3 \\
\hline Hispanic/Latino & 4.64 & 17.66 & 4.83 & 18 & 4.79 & 17.8 \\
\hline Pacific Islander & 0.14 & 0.17 & 0.16 & $<1$ & 0.19 & 0.2 \\
\hline White/Caucasian & 76.8 & 61.72 & 76.35 & 61 & 75.97 & 61.3 \\
\hline Two or more races & 1.42 & 2.05 & 2.62 & 2 & 2.3 & 2.6 \\
\hline Prefer not to answer & 6.5 & & 6.3 & & 6.32 & \\
\hline
\end{tabular}

Appendix A: American Philosophical Association Membership by Race/Ethnicity (U.S. Census Bureau, n.d.; Duffin, 2019; KFF, n.d.) 


\begin{tabular}{|c|c|c|}
\hline Country/Region of Submitting Author & No. of Manuscripts & Percentage \\
\hline Australia & 5 & $3.30 \%$ \\
\hline Austria & 5 & $3.30 \%$ \\
\hline Belgium & 1 & $0.70 \%$ \\
\hline Brazil & 1 & $0.70 \%$ \\
\hline Canada & 11 & $7.30 \%$ \\
\hline Chile & 2 & $1.30 \%$ \\
\hline China & 1 & $0.70 \%$ \\
\hline Colombia & 1 & $0.70 \%$ \\
\hline Denmark & 4 & $2.70 \%$ \\
\hline Estonia & 1 & $0.70 \%$ \\
\hline France & 4 & $2.70 \%$ \\
\hline Germany & 12 & $8.00 \%$ \\
\hline India & 3 & $2.00 \%$ \\
\hline Israel & 1 & $0.70 \%$ \\
\hline Japan & 1 & $0.70 \%$ \\
\hline Korea (Republic of) & 2 & $1.30 \%$ \\
\hline Netherlands & 4 & $2.70 \%$ \\
\hline Spain & 4 & $2.70 \%$ \\
\hline Switzerland & 4 & $2.70 \%$ \\
\hline $\begin{array}{l}\text { United Kingdom of Great Britain and } \\
\text { Northern Ireland }\end{array}$ & 13 & $8.70 \%$ \\
\hline
\end{tabular}

Appendix B: Manuscripts Received (Detailed) for the Annual Meeting of the Society for Business Ethics (based on all manuscripts with a submission date of Nov 1, 2017 or later) 
Rubiná Mahsud is a thought leader in business education, corporate strategy, and leadership. She obtained a masters degree in public health, her Ph.D in management from the State University of New York at Albany, and currently serves as an Associate Professor of Management at the Center for Leadership Formation of the Albers School of Business and Economics at Seattle University. Her work spans a wide range of topics from humanitarian services to return on shareholder equity, and her articles have appeared in the Journal of Managerial Psychology, the Journal of Leadership and Organizational Studies, Personnel Review, and Business and Society Review. Dr. Mahsud's previous degrees include a masters in social sciences from the University of Birmingham (U.K.) and a medical degree from Jinnah Medical College (Pakistan).

Jessica Ludescher Imanaka is an Associate Professor at the Albers School of Business and Economics at Seattle University, where she holds a joint appointment in both management and philosophy and teaches ethical reasoning in business, ethics in business, business ethics and social responsibility, spiritual business, and select philosophy classes. Dr. Imanaka's research has focused on corporate social responsibility, the theory of the firm, political economy, sustainability, environmental justice, globalization, the philosophy of technology, and Catholic social thought. Her papers have appeared in The Harvard International Review, Business and Society Review, The Independent Review, Environmental Ethics, The Journal of Catholic Social Thought, The Journal of Jesuit Business Education, Somatics Journal, The Journal of Management for Global Sustainability, and the International Journal of E-Business Research. 